\title{
\begin{tabular}{l|l|l} 
& Jurnal Kependidikan Dasar & Volume :3 \\
Nomor : 2 \\
Tslam Berbasis Sains & Tahun :2018 \\
\hline
\end{tabular}
}

\section{Peran Kesenian Tradisional Dongkrek Sebagai Media Pendidikan Nilai}

\author{
Moral \\ Farida Sekti Pahlevi \\ Dosen Ilmu Hukum \\ Institut Agama Islam Negeri Ponorogo \\ faridapo55@gmail.com
}

\begin{abstract}
Abstrak
Penelitian ini bertujuan untuk mengetahui dan mendeskripsikan tentang peran kesenian tradisional dongkrek sebagai media pendidikan nilai moral. Penelitian menggunakan metode deskriptif dengan pendekatan kualitatif. Alat pengumpulan data adalah wawancara, observasi, dan dokumentasi. Proses analisis data dengan mereduksi, menyajikan, dan menyimpulkan data. Hasil penelitian menunjukkan bahwa (a) kesenian tradisional Dongkrek tetap menjaga keaslian Kesenian tradisional Dongkrek; (b) Tata cara pagelaran kesenian tradisional Dongkrek di bagi menjadi tiga tahap yaitu tahap pra acara, tahap acara inti dan tahap penutupan; (c) Nilai moral yang terkandung dalam kesenian tradisional Dongkrek diantaranya adalah nilai kebersamaan/gotong royong, nilai keindahan, nilai kebenaran,nilai kebaikan, nilai tanggung jawab,nilai ketaatan, nilai keburukan atau kejahatan, nilai kejujuran, nilai kepercayaan; (d) Kesenian tradisional Dongkrek yang ada di Sanggar Krido Sakti tidak hanya sebagai ritual dan hiburan saja, tetapi dapat dijadikan sebagai media pendidikan pada waktu mengadakan latihan ataupun pagelaran; (e) Masyarakat Desa Mejayan sangat mendukung dikarenakan fungsi kesenian tradisional Dongkrek dinilai sangat potensial sebagai tontonan dan tuntunan bagi masyarakat.
\end{abstract}

Kata kunci: kesenian tradisional dongkrek, media pendidikan, nilai, moral

\section{Abstract}

The research aims to find out and describe the role of traditional dongkrek art as a medium of moral value education. Research using descriptive methods with a qualitative approach. Data 
collection tools are interviews, observation, and documentation. The process of analyzing data by reducing, presenting, and summarizing data. The results showed that (a) Dongkrek traditional art while maintaining the authenticity of Dongkrek traditional art; (b) The procedures for performing traditional Dongkrek arts are divided into three stages: the preevent stage, the core program stage and the closing stage; (c) The moral values contained in the traditional arts of Dongkrek include the value of togetherness / mutual cooperation, the value of beauty, the value of truth, the value of goodness, the value of responsibility, the value of obedience, the value of evil or evil, the value of honesty, the value of trustworthiness; (d) Dongkrek traditional art in Sanggar Krido Sakti is not only for rituals and entertainment, but can be used as an educational medium when conducting exercises or performances; (e) The people of Mejayan Village are very supportive because the function of Dongkrek traditional art is considered to be very potential as a spectacle and a guide for the community.

Keywords: traditional dongkrek art, educational media, values, moral.

\section{Pendahuluan}

Aset bangsa yang sangat berharga baik dari aspek ekonomi, sosial, maupun budaya salah satunya adalah adanya kesenian tradisional . Sebagai aset ekonomis, kesenian tradisional terbukti memiliki nilai komersil yang tinggi dengan banyaknya penerimaan serta apresiasi dari dunia internasional. Kesenian tradisional adalah warisan budaya yang memiliki arti penting bagi kehidupan adat dan sosial karena di dalamnya terkandung nilai, kepercayaan, dan tradisi, serta sejarah dari suatu masyarakat lokal. Kesenian tradisional tidak hanya berfungsi sebagai hiburan saja, namun di dalamnya terkandung penghormatan terhadap arwah leluhur dan nilai-nilai magis religius lainnya.
Kesenian tradisional Dongkrek adalah peninggalan leluhur yang harus dilestarikan, karena mempunyai nilai-nilai kehidupan manusia yang indah untuk dilihat dan menarik untuk dihayati maknanya sebagai kesenian tradisional milik daerah. Dengan kemajuan IPTEK, maka senipun dapat dijadikan sebagai media pendidikan nilai-nilai moral pada masyarakat. Hal ini sesuai dengan Pasal 1 Nomor 2 Undang-Undang Nomor 20 Tahun 2003 tentang Sistem Pendidikan Nasional yang berbunyi "Pendidikan Nasional adalah pendidikan yang berdasarkan Pancasila dan UndangUndang Dasar Negara Republik Indonesia Tahun 1945 yang berakar pada nilai-nilai agama, kebudayaan nasional Indonesia, dan tanggap terhadap tuntutan zaman". ${ }^{1}$

\footnotetext{
${ }^{1}$ Sukarnoputri, Undang-Undang Nomor 20 Tahun 2003 Tentang Sistem Pendidikan Nasional.
} 
Kesenian tradisional Dongkrek merupakan salah satu unsur kebudayaan Jawa dan Indonesia yang banyak mengandung nilai etis dan estetika yang sangat berharga untuk dipelajari. Kesenian tradisional Dongkrek memiliki kontribusi yang banyak bagi pendidikan didalam masyarakat, karena didalam setiap pementasan, kesenian tradisional Dongkrek menyampaikan berbagai nilainilai pesan moral yang dapat memberikan pendidikan bagi masyarakat (penonton) khususnya memuat nilai-nilai yang berharga dalam kehidupan bermasyarakat.

Kesenian tradisional Dongkrek secara filosofis memiliki makna dan fungsi sebagai ritual tolak bala. Kesenian tradisional dongkrek pada awalnya dilakukan sebagai tarian untuk mengusir wabah penyakit, bencana alam, dan roh jahat yang terjadi dalam kehidupan masyarakat di kecamatan Caruban yang sekarang berganti menjadi kecamatan Mejayan pada tahun 1867. Masyarakat sangat dipengaruhi oleh kesenian tradisional Dongkrek ini karena di dalamnya terkandung nilai-nilai moral yang dapat dijadikan pedoman oleh masyarakat. Fungsi kesenian adalah sebagai sarana untuk melibatkan masyarakat secara langsung. Sifat masyarakat yang membutuhkan suatu tuntunan sekaligus hiburan, maka dari itu kesenian tradisional Dongkrek sangat melekat dihati masyarakat madiun pada khususnya.nilai ritual dan magis sangat erat didalam kesenian tradisional dongkrek ini, sehingga mempunyai nilai istimewa dilingkungan masyarakat madiun dan luar madiun.

Pemanfaatan budaya rakyat (folk cultur) di Indonesia selayaknya perlu diperhatikan oleh semua pihak, karena budaya memiliki peranan penting dalam kehidupan masyarakat. Kesenian tradisional Dongkrek yang tetap diminati pertunjukannya disebabkan oleh beberapa faktor kedekatan budaya, yaitu bahasa yang dipergunakan. Masyarakat lebih mudah meahami akan nilai dan maksud kesenian tradisional Dongkrek melalui komunikasi yang sudah mereka kenal dengan menggunakan bahasa Indonesia dan Jawa.

Sebuah bangsa bisa disebut sebagai bangsa yang maju dan kuat apabila nilainilai dasar yang menjadi pedomannya benar-benar termanifestasi dalam perilaku sehari-hari. Sehingga dalam kehidupan berbangsa tidak ada lagi perilaku penyimpangan, penyelewengan, penjajahan, diskriminasi dan perilakuperilaku negatif lainnya. Namun, dewasa ini bangsa Indonesia seolah sedang berada pada posisi yang sangat rapuh. Berbagai permasalahan kian menjamur mengotori bangsa ini. Hampir disetiap lini dan sektor kehidupan tidak luput dari permasalahan yang tidak kunjung terselesaikan. ${ }^{2}$

Pendidikan merupakan unsur terpenting suatu negara yang harus diperhatikan. Sistem pendidikan yang tepat maka akan membawa kemajuan bagi suatu negara dan begitupun sebaliknya disaat sistem pendidikan tidak tepat maka

\footnotetext{
2 Pahlevi, “REAKTUALISASI PANCASILA SEBAGAI UPAYA PENINGKATAN KUALITAS PENDIDIKAN MORAL BANGSA INDONESIA."
} 
kemajuan negara di pertaruhkan. Kehidupan berbangsa dan bernegara Indonesia mengalami suatu perubahan dan perkembangan yang sangat besar. Kondisi kerapuhan bangsa ini harus segera dicarikan solusi dan dihentikan. Oleh karenanya, diperlukan upaya serius untuk mengembalikan etika dan moral bangsa agar bisa kembali pada nilai-nilai yang luhur. Dan untuk itu, diperlukan sebuah patokan nilai yang bisa diterima oleh seluruh elemen bangsa yang majemuk ini. Sebuah nilai yang tidak bias dan ambigu, melainkan nilai yang mampu mengakomodir seluruh ide-ide masyarakat. Mengembalikan moral dan etika ditengah-tengah kondisi bangsa mejemuk yang sudah rapuh memang bukan perkara mudah. Butuh perjuangan keras untuk mewujudkannya, dan pendidikan Pancasila mulai direaktualisasikanlah yang paling tepat untuk kondisi saat ini. Batasan tentang pendidikan seperti sifat sasarannya yaitu manusia, mengandung banyak aspek dan sifatnya sangat kompleks. Karena sifatnya yang kompleks itu maka tidak sebuah batasanpun yang cukup memadai untuk menjelaskan arti pendidikan secara lengkap. Batasan tentang pendidikan yang dibuat oleh para ahli beranekaragam, dan kandungannya berbeda satu dari yang lainnya. ${ }^{3}$

\section{Metode Penelitian}

Pendekatan yang digunakan adalah pendekatan deskriptif kualitatif dengan metode studi kasus. Penelitian kualitatif adalah penelitian yang

\footnotetext{
${ }^{3}$ Umar Tirtaraharja dan Sulo. Pengantar Pendidikan (Jakarta: Rineka Cipta, 2005), 33-35
}

bermaksud untuk memahami fenomena tentang apa yang dialami oleh subjek penelitian secara holistic, dengan cara deskripsi dalam bentuk kata-kata dan bahasa, pada suatu konteks khusus yang alamiah dan dengan memanfaatkan berbagai metode alamiah. ${ }^{4}$ Tujuan dari penelitian deskriptif adalah untuk memberikan deskripsi, gambaran atau lukisan secara sistematis, faktual dan akurat, fakta-fakta, sifat-sifat serta hubungan antarfenomena yang diselidiki. Teknik pengumpulan data dalam penelitian menggunakan observasi langsung, komunikasi langsung, dokumentasi, triangulasi, dan studi literatur. Agar penelitian dapat dilakukan secara mendalam, maka subjek yang diteliti adalah Pendiri dan Penasihat sanggar "Krido Sakti", Pelaku seni Dongkrek, siswa sekolah yang belajar kesenian dongkrek, Tokoh masyarakat dan masyarakat sebagai penonton kesenian tradisional Dongkrek, Kepala Sub. Bagian Kebudayaan Dinas Pendidikan Kabupaten Madiun, Kepala Desa Ibu Titik Handayani dan Perangkat Desa Mejayan Kecamatan Mejayan Kabupaten Madiun

\section{Sejarah kesenian tradisional "Dongkrek" di Desa Mejayan Kecamatan Mejayan Kabupaten Madiun.}

Kesenian tradisional Dongkrek merupakan sebuah kesenian yang mengisahkan cerita legenda di wilayah kabupaten Madiun tepatnya di Desa Mejayan Kecamatan Mejayan. Bentuk dan model kesenian Dongkrek hampir sama

\footnotetext{
${ }^{4}$ Moleong, Metodologi Penelitian Kualitatif.
} 
dengan sendratari yang tidak disertai dialog. Kesenian tradisional Dongkrek menggunakan topeng, karena itu juga disebut seni drama topeng.

Arti dari Dongkrek yaitu Donganipun kawulo(rakyat) Enggal Keraharjan (do'a rakyat semoga diberi keselamatan). Istilah Dongkrek berasal dari bunyi dua buah tabuhan yang mendominasi suara gamelan yang mengiringi tarian. Kata "Dung" berasal dari bunyi tabuhan bedug sedangkan kata "krek" berasal dari bunyi Korek. Apabila kedua alat tersebut dimainkan secara beraturan maka akan terdengan bunyi dung... krek...dung... krek... dan seterusnya. Dari bunyi itulah maka lahirlah istilah di kalangan Mejayan untuk menyebut sebagai Dongkrek.

Sanggar Krido Sakti adalah sanggar kesenian yang bergerak dalam bidang Dongkrek yang ada di Dusun Gendoman Desa Mejayan Kecamatan Mejayan Kabupaten Madiun. Di tengah pengaruh budaya luar yang semakin luas, Sanggar Krido Sakti tetap gagah berdiri. Sanggar Krido Sakti didirikan oleh Mbah Dul Rokhim seorang Paripurna TNI AU asli kelahiran Malang Jawa Timur. Beliau menikah dengan orang Madiun dan bertempat tinggal di Dusun Gendoman Desa Mejayan Kecamatan Mejayan Kabupaten Madiun dan 79 enal Dongkrek. Ketertarikan dan kecintaan terhadap Dongkrek itulah yang membuat Mbah Dul Rokhim mendirikan Sanggar Krido Sakti pada Tahun 1979 dan baru mendapatkan nomor Induk pada tahun 2003 serta pada tahun 2009 mendapatkan Keputusan Bupati bahwa Dongkrek sebagai Kesenian khas Kabupaten Madiun.
Lahirnya kesenian Dongkrek yaitu pada tahun 1867 di Mejayan yang diciptakan oleh Raden Ngabei Lo Prawirodipoero yang pada masa itu menjabat sebagai Palang di Mejayan (Caruban). Raden Ngabei Lo Prawiridipoero merupakan Palang terakhir dalam sitem pemerintahan pada waktu itu sampai wafatnya \pm tahun 1915/1916.

Dimulai dengan adanya Pageblug (wabah penyakit) di Desa Mejayan, kecamatan Mejayan Kabupaten Madiun. Pageblug yaitu wabah penyakit yang konon sangat berbahaya karena pagi sakit sore meninggal, sre sakit pagi meninggal. Keadaan yang sangat memilukan itu membuat Eyang Palang (R. Ngabei Lo Prawirodipoero) merasa iba atas penderitaan rakyatnya. Eyang Palang kemudian mengadakan musyawarah dengan para segenap pejabat di Desa Mejayan untuk menumpas pageblug tersebut, namun keputusannya yaitu semua persoalan diserahkan sepenuhnya kepada Eyang Palang.

Eyang Palang kemudian sowan ke rumah Bapaknya yaitu Eyang Kanjeng Raden Tumenggung Prawirodipoero II untuk meminta petunjuk. Oleh bapaknya Eyang Palang disuruh menyepi di suatu tempat yaitu di Gunung Kidul Madiun untuk bertapa memohon petunjuk kepada Sang Pencipta. Dalam tapa bratanya di bawah pohon rindang, Eyang Palang digoda oleh para jin, setan, peri, banas pati serta bangsa lelembut lainnya. Pada waktu itu terjadilah perkelahian yang sangat sengit antara Eyang Palang dengan bangsa Ghoib tersebut dan dimenangkan oleh Eyang Palang. 
Kesaktian dan dengan kebersihan hatinya Eyang Palang bisa mengalahkan para lelembut, lelembut yang telah kalah tersebut akhirnya tunduk dan patuh kepada Eyang Palang. Setelah terjadi pengakuan kekalahan tersebut maka terjadi percakapan dan negosiasi antara Eyang Palang dengan Para lelembut tersebut. Hasilnya para lelembut tersebut diperintahkan oleh Eyang Palang untuk mengelilingi Desa Mejayan mengusir Pageblug yang disebabkan oleh roh halus yang jahat. Pada saat itulah terjadi peperangan antara para roh halus yang baik (tunduk pada Eyang Palang) dengan para roh halus yang menyebarkan pageblug. Peperangan tersebut dimenangkan oleh roh halus yang tunduk pada Eyang Palang. Sesampai di Pendopo Palangan para roh halus tersebut di suruh pulang ke alamnya, namun apabila sewaktu-waktu dibutuhkan maka akan dipanggil untuk menjaga keselamatan para rakyat atas izin yang Maha Kuasa.

Eyang Raden Ngabei Lo Prawirodipoera di lain kesempatan mengumpulkan para tokoh masyarakat untuk membuat topeng seperti roh halus yang pernah mengganggu beliau berupa Genderuwo, Perot dan lainnya. Selanjutnya disuruh menarikan dengan diiringi musik yang telah dibuatnya suara musik terdengar "dung" dari bunyi bedug dan “krek" dari bunyi korek. Dari bunyi dung.... krek... itulah kemudian melahirkan istilah Dongkrek. Dongkrek mempunyai makna filosofi juga yaitu Donganipun kawulo enggal keraharjan.

\footnotetext{
${ }^{5}$ Bastomi, Wawasan Seni.
}

Instrumen Dongkrek terdiri dari korek, bedug, kentongan bambu, kecer, kendang, kenong, beri dan kempul. Topeng Dongkrek terdiri dari; 1)Empat buah topeng genderuwo/hantu, 2) Dua buah topeng wanita, 3) 1 buah topeng orang tua. Perlengkapan tari Dongkrek terdiri dari: dua buah keris dan dua buah pedang kayu yang dipakai oleh penari raksasa, satu buah tongkat dari kayu yang dipakai oleh penari orang tua.

Dongkrek bisa dikatakan sebagai seni yang diciptakan oleh Raden Ngabei Lo Prawirodipoero dengan melalui berbagai proses, hal ini sependapat dengan pendapat Paul Klee dalam Bastomi ${ }^{5}$ yang menyatakan bahwa, "seni bukan tiruan alam atau terjemahan alam, melainkan pernyataan gagasan yang utuh dari dalam diri seseorang dan gagasan itu menjadi wujud yang dapat diamati dan dinikmati". Selain pendapat para ahli tersebut seni juga diartikan sebagai buah karya manusia yang berbentuk lahiriah yang menjadi wadah kehidupan perasaan manusia yang bersifat artistik. Kemudian seni juga diartikan sebagai suatu proses, yaitu seseorang memperoleh dan terpesona ketika ia sedang aktif memproses terwujudnya suatu seni.

Peneliti berpendapat bahwa istilah Dongkrek diambil dari penyingkatan harapan para rakyat Mejayan pada masa itu yaitu Donganipunkawulo enggal keraharjan. Istilah Dongkrek juga lahir karena ditimbulkan oleh instrumen musik yang digunakan. Kesenian tradisional Dongkrek lahir pada tahun 1867 oleh Raden Ngabei Lo Prawirodipoero. Sanggar 
Krido Sakti mempunyai makna "karya (krido) seseorang yang mempunyai kelebihan dapat menemukan sesuatu yang dipergunakan untuk mengusir wabah (pageblug)".

\begin{tabular}{|c|c|c|}
\hline Pagelaran & Kesenian & Tradisional \\
\hline “Dongkrek” & di Desa & Mejayan \\
\hline $\begin{array}{l}\text { Kecamatan } \\
\text { Madiun. }\end{array}$ & Mejayan & Kabupaten \\
\hline Dalam & pagelaran & kesenian \\
\hline
\end{tabular}
tradisional Dongkrek tidak memerlukan suatu panggung tertentu. Kesenian tradisional Dongkrek dapat dilaksanakan dalam lapangan terbuka Syarat-syarat dalam pelaksanaan ritual pagelaran Dongkrek salah satunya yaitu adanya sesaji. Sesaji hanya diadakan pada bulan Suro saja dalam kesenian Tradisional Dongkrek ditujukan kepada para Leluhur Mejayan, diluar bulan Suro tidak menggunakan sesaji. Pagelaran kesenian tradisional Dongkrek mempunyai tahapan-tahapan atau tata cara dalam pementasannya. Adapun prosesi dalam kesenian tradisional Dongkrek Sanggar Krido Sakti yang masih sangat dihormati adalah tata cara kebudayaan Jawa di imbangi dengan unsur ajaran agama Islam. Tahapan-tahapan tersebut adalah:

\section{a. Tahap Pra Acara}

Sebelum pagelaran kesenian tradisional Dongkrek banyak hal yang harus dipersiapkan yaitu mempersiapkan panggung pagelaran. Gamelan-gamelan yang akan digunakan oleh panjak gamelan dongkrek disiapkan terlebih dahulu dipanggung. Panjak Gamelan Dogkrek, narator Dongkrek, penari Dongkrek berkumpul diluar panggung terlebih dahulu untuk berdo'a memohon kelancaran dalam pagelaran kepada Tuhan Yang Maha Esa. Panjak gamelan Dongkrek dan narator masuk panggung terlebih dahulu dengan berbaris teratur, kemudian narator membuka acara.

\section{b. Tahap Acara Inti}

Pada tahap acara inti ini adalah tahap kesenian tradisional Dongkrek dimulai. Selama pagelaran dimulai dari awal sampai akhir yang menyampaikan alur cerita adalah narator. Pertamakali yang dibunyikan dalam pementasan adalah bedug yang berbunyi "Dung" kemudian kentngan yang bunyinya thuk... thuk... thor... dan diteruskan dengan bunyi korek "krekk..." dan seterusnya. Setelah itu berhenti sejenak dilanjutkan dengan bunyi kendang yang keras dan diikuti oleh instrumen gamelan lainnya. Para penari masuk kepanggung setelah mendapatkan kode ataupun arahan dari narator.

Penari perempuan berjumlah 5 (lima) orang menari masuk panggung mengawali kesenian tradisional Dongkrek membentuk lingkaran beberapa kali. Penari perempuan menari dengan ceria kemudian tiba-tiba bunyi gamelan terdengar keras, mistik dan seram diiringi jeritan para penari kesakitan. Datanglah penari orang tua yang melihat mengitari para penari perempuan yang menjerit kesakitan terkena wabah. Merasa iba penari orang tua mengajak ke pendopo untuk dilindungi dan akan mencari cara mengusir pageblug. Penari orang tua dan lima perempuan keluar panggung.

Masuklah dua peneri perempuan memakai topeng cantik dan perot menari membentuk lingkaran dengan beberapa gerakan tangan kanan melambai, 
menunjuk dan jari telunjuk di taruh didepan bibir. Kemudian datanglah segerombolan penari genderuwo berjumlah 4 (empat) orang penari memakai topeng merah, putih, hitam dan hijau. Menari mengitari dua penari perempuan dan penari peempuan terlihat ketakutan dan menjerit. Dalam keadaan tersebut masuklah ke panggung penari orang tua untuk menyelamatkan kedua perempuan itu. Terjadilah tarian yang gerakannya menunjukkan perkelahian yang sangat dahsyat. Dengan tongkat janur kuning Orang tua bisa mengalahkan para penari Genderuwo. Dan para penari genderuwo menyembah orang tua sakti sebagai ungkapan meinta maaf, taat, dan siap membantu mengusir pageblug di Mejayan.

Kemudian semua penari menari dengan gerakan melingkar beberapa kali dengan urutan orang tua di depan, kemudian para penari perempuan dan dilanjutkan oleh penari genderuwo dan keluar panggung. Dengan demikian seesailah pagelaran Dongkrek yang berlangsung \pm 20 menit.

c. Tahap Penutupan

Setelah semua penari Dongkrek keluar dari panggung dan alur cerita sudah disampaikan, maka dilanjutkan dengan penutupan. Pagelaran kesenian Tradisional Dongkrek ditutup dengan ucapan terimakasih dan serangkaian do'a dan diiringi dengan Sholawat. Dalam pagelaran kesenian tradisional Dongkrek juga terdapat tata cara dalam menyampaikan alur cerita Dongkrek.

\footnotetext{
${ }^{6}$ Sudarsono, Seni Pertunjukan Indonesia Di Era Globalisasi.
}

Narator dalam menyampaikan alur cerita bisa ditambah dengan pesan-pesan yang bermanfaat bagi kehidupan bermasyarakat dan beragama

Fungsi kesenian tradisional Dongkrek selain sebagai tontonan juga sebagai sarana ritual, hal ini sejalan dengan pendapat Soedarsono ${ }^{6}$ yang menyatakan bahwa seni pertunjukan di Indonesia berfungsi sebagai sarana ritual. Dan ditambah dengan temuan penelitian oleh Gazalba ${ }^{7}$ bahwa hakikat fungsi kesenian itu untuk memberikan hiburan.

Temuan tentang sesajen yang ditujukan kepada para leluhur dalam kesenian Dongkrek selaras dengan pendapat Yunus yang menyatakan bahwa kesenian merupakan tindakan komunikasi baik vertikal maupun komunikasi horisontal yang menyebutkan bahwa komunikasi vertikal berlangsung antara pendukung kesenian dengan kekuatan supranatural yang diyakini melalui proses tertentu. Namun hal tersebut bertentangan dengan norma agama seperti yang disampaikan oleh Wahyu Rochmadi bahwa norma agama adalah aturan-aturan hidup yang bersumber dari wahyu Tuhan yang Maha Esa.

\section{Nilai-Nilai Moral Yang Terkandung Dalam Kesenian Tradisional "Dongkrek" Di Desa Mejayan Kecamatan Mejayan Kabupaten Madiun.}

Nilai-nilai moral yang terkandung dalam kesenia tadisional Dongkrek meliputi:

\footnotetext{
${ }^{7}$ Gazalba, Antropologi Budaya Gaya Baru: Untuk Perguruan Menengah Islam, Perguruan Menengah Umum Tingkat Pengetahuan Menengah.
} 
a. Nilai kebersamaan/gotong royong tampak pada waktu seluruh pemain Dongkrek saling bekerja sama dan gotong royong dalam mengadakan latihan, dalam mempersiapkan keperluan pagelaran kadangkala juga diwaktu salah satu dari pemain atau warga ada yang membutuhkan bantuan maka akan dibantu. Selain dari kegiatan tersebut makna nilai-nilai kebersamaan juga terkandung dalam setiap gerakan penari, misalnya disaat alur cerita bahwa rakyat Mejayan bersama-sama hidup berdampingan suka maupun duka, itu sudah mengandung arti kebersamaan dan gotong royong.

b. Nilai keindahan, tampak pada sajian pagelaran yang menggunakan perlengkapan khas Jawa jadi terlihat indah, mulai dari gamelan, busana yang dipakai dan topeng Dongkrek, selain itu keindahan juga terlihat diwaktu para pemain gamelan memainkan musik gamelan terdengar merdu dan indah apalagi ditambah dengan gerakan para penari Dongkrek sungguh indah.

c. Nilai kebenaran, tampak pada saat pemain benar-benar membawakan atau memainkan Dongkrek dengan sungguh-sungguh dari jiwanya tanpa ada paksaan, Selain itu juga tampak pada saat penari orang tua dalam perkelahiannya bisa mengalahkan para penari Genderuwo yang menebar pageblug (wabah), ini berarti bahwa kebenaran atau kebaikan pasti akan mengalahkan kejahatan.

d. Nilai kebaikan, tampak pada waktu latihan pasti akan diajarkan tentang kebaikan dan dijelaskan bahwa Dongkrek dibuat untuk mengusir pageblug yang disebabkan oleh para makhluk yang jahat. Kemudian juga tampak pada saat penari orang tua yang berusaha menolong rakyatnya yang terkena pageblug, orang tua mempunyai keyakinan bahwa kebaikan pasti akan menang.

e. Nilai tanggung jawab,disini para pemain Dongkrek sangat bertanggung jawab baik dalam hal urusan sanggar ataupun permainannya, misalnya saja pak Marianto itu sebagai pembuat topeng Dongkrek satu-satunya di Madiun walaupun banyak sekali pesanan, maka dia tidak akan melemparkan tanggung jawabnya, dia akan mengerjakannya dengan bantuan saudara dalam hal tertentu saja, Kemudian nilai tanggung jawab juga tampak pada Mbah Dul yang bertanggung jawab terhadap sanggar Krido Sakti dengan dibantu Pak Walgito dan pengurus/pemain lainnya. Selain itu juga tampak pada saat penari orang tua yang berperan sebagai Raden Ngabei Lo Prawirodipoero menjabat Palang Desa Mejayan bertanggung jawab atas segala hal yang terjadi di Desanya terutama pada rakyatnya. Dengan segala kemampuan dia bertanggung jawab, dengan mempertaruhkan jiwa dan raga.

f. Nilai religius, tampak dalam setiap do'a yang ditujukan kepada Tuhan yang Maha Esa dalam hal apapun baik dalam latihan ataupun pagelaran selalu memohon pertolongan Allah SWT, selain itu juga tampak pada saat penari berusaha mengusir Genderuwo dengan memohon pertolongan Allah SWT. 
g. Nilai kejujuran, tampak pada gerakan dua penari topeng perempuan yang meletakkan jari telunjuknya didepan bibir sebagai isyarat bahwa harus berkata jujur tidak boleh bohong dan agar selalu menjaga ucapan.

h. Nilai kepercayaan, tampak pada masyarakat Mejayan khususnya pemain Dongkrek bahwa mereka percaya terhadap hal-hal Ghoib. Mereka mempercayai adanya makhluk yang diciptakan oleh Allah SWT selain manusia, kemudian tampak pula dalam alur cerita yang mengatakan bahwa manusia harus percaya kepada Allah SWT dan dengan segala yang diciptakan termasuk setan dan jin.

i. Nilai keburukan atau kejahatan, tampak pada penari pemeran genderuwo sebagai penyebab pageblug atau wabah di Desa Mejayan,dan hal ini tidak diajarkan tetapi hanya di sampaikan bahwa keburukan dan kejahatan itu tidak baik.

Temuan tentang nilai-nilai moral memang bermanfaat bagi kebudayaan. Hal ini selaras dengan pendapat liliweri ${ }^{8}$ yang menyatakan bahwa Nilai merupakan sesuatu yang abstrak tentang tujuan budaya yang akan kita bangun bersama melalui bahasa, simbol, dan pesan-pesan verbal maupun nonverbal. Nilai atau value mengandung pengertian sesuatu yang berharga. Sesuatu yang bernilai apabila memiliki nilai guna (memiliki keindahan) kebenaran atau kebaikan, misalnya sesuatu yang baik berarti memiliki nilai moral (nilai kebaikan). Nilai itu sesuatu yang abstrak, tidak konkret, dapat dipikirkan, dipahami, dihayati, dijiwai, dan berhubungan dengan cita-cita, harapan, keyakinan, hal-hal yang bersifat batiniah, dan bersifat ideal, bukan faktual.

Orang muda menghormati orang tua serta di dalam melakukan apapun hendaknya memohon kepada Tuhan Yang Maha Kuasa dengan di imbangi dengan hati yang bersih dan suci. Hal inilah yang juga bisa didapatkan dari Dongkrek, selain itu juga mengingatkan bahwa di muka bumi ini Manusialah makhluk Tuhan yang paling Mulia, akan tetapi manusia juga harus menyadari bahwa Tuhan menciptakan banyak Makhluk, diantaranya adalah makhluk Ghoib yang harus kita akui keberadaannya.

Dari sinilah peneliti menyimpulkan bahwa "keburukan akan kalah dengan kebaikan" atau kejahatan akan kalah oleh kebenaran" nilai-nilai moral tersebut diatas adalah yang terkandung dalam kesenian tradisional Dongkrek.

Pembelajaran Nilai-Nilai Moral Melalui Kesenian Tradisional Dongkrek Pada Sanggar Krido Sakti Di Dusun Gendoman Desa Mejayan Kecamatan Mejayan Kabupaten Madiun.

Sanggar Krido Sakti sangat diminati oleh para seniman ataupun masyarakat. Karena disinilah Dongkrek dalam kemasan aslinya bisa ditemukan dan dipelajari. Sanggar Krido Sakti terlihat dari Luar sudah bisa ditebak bahwa selalu terbuka untuk siapa saja yang tujuannya sudah tentu tentang Dongkrek. pada awal kedatangan peneliti kesana sudah langsung menemukan sanggar Krido Sakti

\footnotetext{
${ }^{8}$ Liliweri, Makna Budaya Dalam Komunikasi Antarbudaya, 50.
} 
karena memang pintu selalu terbuka mulai dari jam 08.00-sore bahkan malam. Di depan sanggar terdapat tulisan PAGUYUBAN KRIDO SAKTI KABUPATEN MADIUN, dan ternyata Sanggar tersebut merupakan rumah pribadi Mbah Doel Rokim. Kecintaan terhadap Dongkrek Mbah Dul mengabdikan diri untuk Dongkrek, rumahpun diberikan untuk Dongkrek sepenuhnya. Rasa kecintaan dan kepedulian terhadap Pusaka Dongkrek yang sekarang menjadi kesenian tradisional Dongkrek warisan leluhur membuat seseorang berhati mulia dan menjunjung tinggi nilai-nilai kebaikan.

Di sanggar Krido Sakti inilah Mbah Doel Rokim beserta pengurus Sanggar lainnya mengajarkan Dongkrek baik kepada masyarakat, siswa-siswi sekolah bahkan kepada orang-orang luar Mejayan yang berkunjung. Nilai-nilai moral selalu diajarkan, bahwa kejahatan dan keburukan itu tidak akan pernah abadi dan mendapat perlindungan dari Tuhan Yang Maha Esa. Nilai-nilai moral dalam kesenian tradisional Dongkrek diajarkan dengan cara tanya jawab, diskusi ataupun obrolan biasa disaat latihan Dongkrek di sanggar Krido Sakti. Dikaitkan dengan keadaan yang ada membuat peserta latihan lebih memahai nilai-nilai moral dan maksud dari kesenian tradisional Dongkrek.

Kesenian tradisional Dongkrek yang mengajarkan nilai-nilai moral membawa pengaruh baik terhadap kebudayaan ataupun moral manusia, hal ini selaras dengan pendapat Budiningsih ${ }^{9}$ yang menyatakan bahwa Kebudayaan akan mempengaruhi cepat lambatnya pencapaian tahap-tahap perkembangan moral dan juga mempengaruhi batas tahap perkembangan yang dicapai. Dengan kata lain, bahwa individu yang mempunyai latar budaya tertentu dapat berbeda perkembangan moralnya dengan individu lain yang berasal dari kebudayaan lain atu perkembangan moral dipengaruhi oleh faktor kebudayaan.

Peneliti berpendapat bahwa pendalaman nilai-nilai moral bisa dilakukan melalui kegiatan-kegiatan atau pengalaman- pengalaman konkret seperti belajar kesenian tradisional Dongkrek di Sanggar Krido Sakti, sehingga nilai-nilai moral tertanam dan terhayati dalam kehidupan. Namun apabila pelaksanaannya dilakukan sekali atau dua kali saja maka akan memperoleh hasil yang kurang optimal. Kesenian tradisional Dongkrek bisa dikembangkan tanpa meninggalkan nilai estetika dan etikanya.

Tanggapan Masyarakat Terhadap Isi Dan Cara Penyampaian Pendidikan Nilai-Nilai Moral Dalam Kesenian Tradisional “Dongkrek” Pada Sanggar Krido Sakti Di Dusun Gendoman Desa Mejayan Kecamatan Mejayan Kabupaten Madiun.

Masyarakat merupakan salah satu aspek penting dalam pagelaran kesenian tradisional Dongkrek, karena tanpa adanya masyarakat maka tidak akan berjalan dengan maksimal. Masyarakat merupakan sasaran utama dari penyampaian pesan-pesan tentang nilainilai moral yang terkandung dalam

\footnotetext{
${ }^{9}$ Budiningsih, Pembelajaran Moral: Berpijak Pada Karakteristik Siswa Dan Budayanya, 5.
} 
kesenian tradisional Dongkrek. Oleh karena itu keberadaan masyarakat dalam kesenian tradisional Dongkrek sangat vital. Tanggapan masyarakat tentang penyampaian pendidikan nilai-nilai moral melalui kesenian tradisional Dongkrek sangat seragam, karena kesenian tradisional Dongkrek berisi tentang kebenaran dan kebaikan mengalahkan keburukan dan kejahatan.

Inti dari seluruh kesenian pada prinsipnya selain sebagai tontonan (pertunjukan) juga sebagai tuntunan. Tuntunan yang disampaikan dalam pagelaran kesenian tradisional Dongkrek mengajarkan bahwa dalam kehidupan sehari-hari pasti akan ada ancaman ataupun bencana olah karena itu maka manusia harus senantiasa berdo'a kepada Tuhan Yang Maha Esa dan berusaha agar bisa menghadapi dengan baik. Karena manusia dikaruniai oleh cipta, rasa dan karsa menjadikan manusia sebagai manusia paling sempurna. Dengan demikian manusia adalah makhluk yang bisa ditata sehingga diharapkan tuntunan atau pendidikan yang disampaikan dalam kesenian tradisional Dongkrek bisa menjadi tatanan yang akhirnya menjadikan manusia sebagai makhluk yang berbudaya.

Temuan penelitian mengenai kesenian tradisional Dongkrek sebagai tontonan (pertunjukan) sekaligus tuntunan selaras dengan pendapat Soedarsono ${ }^{10}$ bahwa perkataan "pertunjukan" dalam "seni pertunjukan" menyarankan sejumlah kegiatan, yakni memperlihatkan, memperagakan dan mendengarkan, atau dengan kata lain meliputi berbagai kegiatan yang menyentuh panca indera, yang tujuan akhirnya adalah menyentuh pikiran, perasaan dan hayal penonton.

Dari data diatas maka peneliti berpendapat bahwa berkembang tidaknya suatu kesenian yang merupakan unsur kebudayaan dipengaruhi juga oleh anggapan masyarakat yang ada di daerah tersebut dan dapat disimpulkan bahwa kesenian tradisional Dongkrek Sanggar Krido Sakti sangat berperan penting dalam penyampaian pendidikan nilai-nilai moral kepada masyarakat.

\section{Kesimpulan}

Berdasarkan hasil penelitian, pada bagian ini dikemukakan kesimpulan penelitian sebagai berikut: Sejarah kesenian tradisional "Dongkrek" di Desa Mejayan Kecamatan Mejayan Kabupaten Madiun yang diciptakan oleh Raden Ngabei Lo Prawirodipoero pada tahun 1867. Sanggar Dongkrek yang ada di Dusun Gendoman Desa Mejayan Kecamatan Mejayan Kabupaten ini bernama Sanggar Krido Sakti yang didirikan oleh Mbah Dull Rokhim pada tahun 1979. Krido Sakti adalah pemberian nama dari Bapak Walgito yang sekarang menjadi ketua Sanggar/ paguyuban Krido Sakti. Mengambil nama Krido Sakti karena memuat makna " karya (krido) seseorang yang mempunyai kelebihan dapat menemukan sesuatu yang dipergunakan untuk mengusir wabah (pageblug). Sanggar Krido Sakti mendapat nomor induk pada Tahun 2003 (IND:2/ DK/

\footnotetext{
${ }^{10}$ Sudarsono, Seni Pertunjukan Indonesia Di Era Globalisasi, 131.
} 
4.4.14.07/0.2003) dan kesenian tradisional Dongkrek kemudian disahkan menjadi kesenian khas Kabupaten Madiun dengan Keputusan Bupati=188.45/ 677/ KPTS/ 402.031/ 2009.

Tata cara pagelaran kesenian tradisional Dongkrek diluar bulan Suro dalam persiapannya tidak menggunakan sesajen yang ditujukan kepada para leluhur. Setiap pagelaran Dongkrek dalam prosesinya dibagi menjadi tiga tahap, yaitu (a) tahap pra acara dengan mempersiapkan panggung pagelaran dan semua perlengkapan kesenian tradisional Dongkrek serta Do'a untuk memohon kelancaran kepada Allah; (b) acara inti yaitu dengan dimulainya pagelaran kesenian tradisional Dongkrek berupa tari Dongkrek yang diiringi oleh gamelan Dongkrek dari awal sampai selesai; (c) dan acara penutupan yaitu dengan serangkaian Do'a seperti Al Fatihah dan Sholawat .

Nilai-nilai moral yang terkandung dalam kesenian tradisional "Dongkrek" di Desa Mejayan Kecamatan Mejayan Kabupaten Madiun. Nilai moral merupakan nilai yang digunakan sebagai dasar, tuntunan, dan tujuan manusia dalam kehidupannya. Nilai moral yang ada pada kesenian tradisional Dongkrek adalah: (a) nilai kebersamaan/gotong royong tampak pada kekompakan dalam keseharian antar pemain Dongkrek; (b) nilai keindahan tampak pada tarian, busana dan musik yang dimainkan oleh pemain kesenian tradisional Dongkrek; (c) nilai kebenaran tampak pada waktu memberikan wejangan untuk memperjuangkan kebenaran; (d) nilai kebaikan tampak pada waktu latihan pasti akan diajarkan tentang kebaikan; (e) nilai tanggung jawab tampak pada para pemain Dongkrek sangat bertanggung jawab baik dalam hal urusan sanggar ataupun permainannya; (f) nilai religius tampak pada setiap do'a yang ditujukan kepada Tuhan yang Maha Esa; (g) nilai keburukan atau kejahatan tampak pada pencerminan pemain genderuwo yang mempunyai watak jahat; (h) nilai kejujuran tampak pada gerakan dua penari topeng perempuan yang mencerminkan bahwa harus berkata jujur tidak boleh bohng dan agar selalu menjaga ucapan; (i) nilai kepercayaan tampak pada percaya terhadap hal-hal Ghoib.

Kesenian tradisional "Dongkrek" sebagai media pendidikan nilai-nilai moral pada Sanggar Krido Sakti di Dusun Gendoman Desa Mejayan Kecamatan Mejayan Kabupaten Madiun. Kesenian tradisional Dongkrek yang ada di Sanggar Krido Sakti tidak hanya sebagai ritual dan hiburan saja, tetapi dapat dijadikan sebagai media pendidikan pada waktu mengadakan latihan ataupun pagelaran. Pada saat latihan maka diadakan diskusi kecil disea-sela latihan untuk pemantapan tari dan gamelan, kemudian setelah latihan selesai maka diberikanlah wejangan-wejangan tentang nilai-nilai moral yang terkandung dalam kesenian tradisional Dongkrek oleh pelatih. Setelah mengetahui isi cerita yang disajikan maka dapat dipahami nilai-nilai yang terkandung di dalam kesenian tradisional Dongkrek. Inti dari kesenian tradisional Dongkrek adalah memberikan gambaran kepada masyarakat bahwa perbuatan jahat akan hancur oleh kebaikan atau 
kebenaran, sehingga dapat dijadikan tauladan.

Tanggapan masyarakat Mejayan terhadap isi dan cara penyampaian pendidikan nilai-nilai moral pada sanggar Krido Sakti cukup baik dan masyarakat antusias terhadap adanya kesenian tradisional Dongkrek sebagai media penyebaran pendidikan moral yang baik.

\section{Daftar Pustaka}

Bastomi, Suwaji. Wawasan Seni. Semarang: IKIP Semarang Press, 1992.

Budiningsih, Asri. Pembelajaran Moral: Berpijak Pada Karakteristik Siswa Dan Budayanya. Jakarta: Rineka Cipta, 2004.

Gazalba, Sidi. Antropologi Budaya Gaya Baru: Untuk Perguruan Menengah Islam, Perguruan Menengah Umum Tingkat Pengetahuan Menengah. Jakarta: Bulan Bintang, 1974. Liliweri, Alo. Makna Budaya Dalam Komunikasi Antarbudaya. Yogyakarta: LKIS Pelangi Aksara, 2007.

Moleong, Lexy J. Metodologi Penelitian Kualitatif. Bandung: Remaja Rosdakarya, 2007.

Pahlevi, Farida. "REAKTUALISASI PANCASILA SEBAGAI UPAYA PENINGKATAN KUALITAS PENDIDIKAN MORAL BANGSA INDONESIA." Al-Adabiya : Jurnal Kebudayaan Dan Keagamaan 9, no. 1 (2014): 21-44.

Sudarsono, RM. Seni Pertunjukan Indonesia Di Era Globalisasi. Yogyakarta: Gadjah Mada University Press, 2002.
Sukarnoputri, Megawati (presiden Republik Indonesia). Undang-Undang Nomor 20 Tahun 2003 Tentang Sistem Pendidikan Nasional, Pub. L. No. UU No 2 Tahun 2003 (2003). 